測定法
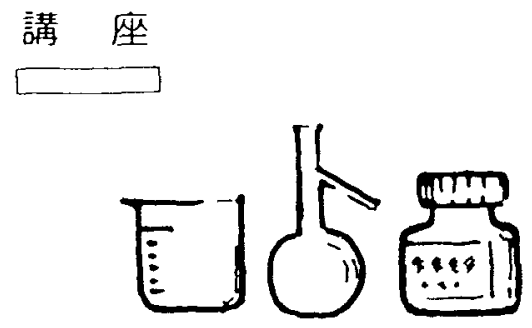

1 はじめに

サイクリックボルタンメトリー(Cyclic Voltammetry, CV 法) は, 電気化学分析法の主要な一つで, その測定 が容易なこともあり，広範な分野で用いられている。こ れは, 時間 $(t)$ に対して線形に变化する電位 $(E)$ の 関数として電流値 $(i)$ を測定し, $i-E-t$ の関係を示 すすのである.この $i$ (つまり正味の電子移動速度)を 決定する因子として，E（つまりエネルギー）や不均一 電子移動速度定数の他に，（ $t$ および濃度の関数として の）拡散や場合によっては溶液中での化学反応速度が挙 げられる ${ }^{1}$. 従って, CV 波とは, 本来平衡論あるいは 速度論に関する豊富な情報を含んでいる，しかしこのこ とが逆に，そしてまたCV 波形そのものが比較的単純 でありお互いに類似していることが，CV 波形の解秎を 妨げていると思われる。このような理由から，一般には 電極反応の初期診断法として用いられる場合が多いここ のCV 法に関しては既に本誌で取り挙げられているの で 2〜4)，出来るだけ重複を避け， CV 波を解釈する上で の基本的知識と注意点について述べたい.

\section{$2 \mathrm{CV}$ 波形について}

一般的な CV 波形については，既に本誌で述べられ ている(2,4)ので詳細は割愛するが, CVでピークが形成 されるのは, 基本的に電極界面での電子移動による界面 濃度变化と界面への物質供給速度が等しくなった時であ る. 従って，ピークの立ち上がり付近では，十分な物質 供給が可能であるので速度論的（あるいは平衡論的 ${ }^{5}$ ) な因子により，またピークの後は，電子移動速度が十分 大きいので拡散により，その波形が支配される．逆掃引 に捛いては, 先の掃引の履歴が残るため, 濃度プロファ イルは多少複雑になるが, 基本的状況は同じである. 化 学反応が付随進行すると, 電極表面あるいは電極近傍で の酸化還元種の濃度に乱れが生ずる，結果として，正味 の電子移動速度や物質移動速度に影響が現れ，ピーク電 位のシフトや波形の変化が引き起こされる。

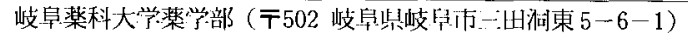

\section{サイクリック ボルタンメトリー}

\section{加 納 健 司}

\subsection{1 段階電子移動}

\section{3 可逆系 $\mathrm{CV}$}

CV 法でいう可逆とは, 電極反応速度定数が掃引速度 （v）に比べ十分に大きく，非可逆的化学反応を伴わない 場合のことである，従って，こうした化学反応を伴わな け机ば，原理的には，vを滅少すれば可逆系にすること ができる．可逆波であることを示す特徴として，ピーク 電流 $\left(i_{\mathrm{p}}\right)$ が $v^{1 / 2}$ に比例すること, ピークセパレーショ ン $\left(\Delta E_{\mathrm{p}}\right)$ がvに依存しないこと等が挙げられる. 1 段 階電子移動系では $\Delta E_{\mathrm{p}}$ は, 約 $59 / n \mathrm{mV}\left(25^{\circ} \mathrm{C} ; n\right.$ : 電 子数）である。またカソードおよびアノード波のピーク の電位の中点は, 非常に良い近似でその系の式量酸化還 元電位 $\left(E^{\circ}\right)$ に等しい. こ机を基に各種平衡論的解析 が可能になる. CV 波を特徴つけるその他の各種パラメー 夕ーについては既報 ${ }^{2,4)}$ を参照されたい。ただし，これ らは, 線形拡散が支配的な場合 (完全平面電極で, $v$ が あまり小さくない場合）についての値である. 電極が微 小あるいは球形でありかつ $v$ が小い場合のように，多 次元拡散が支配的になると状況は異なる. 多次元应散の 寄与の増加と共に, $\Delta E_{\mathrm{p}}$ は増加し, さらにはピークを 形成せず，シグモイド状の定常電流が得られるようにな る. 微小電極の詳細については本誌既報 ${ }^{6,7)}$ を参照され たい.

\section{2 多段階電子移動}

有機・無機の広い分野で扱われる系として多段階電子 移動系がある. Fig. 1 は 2 段階 1 電子移動 $(\mathrm{O} \rightleftarrows \mathrm{S} \rightleftarrows \mathrm{R})$ を例にとり，第 $1(\mathrm{O} / \mathrm{S})$ 第 $2(\mathrm{~S} / \mathrm{R})$ 酸化還元電位の 差 $\left(\Delta E^{\circ} \equiv E_{1}{ }^{\circ}-E_{2}{ }^{\circ}\right)$ に上って波形が变化する様子を 示したものである. $E_{2}{ }^{\circ}$ が $E_{1}{ }^{\circ}$ に比べ，十分負側に位置 するとき $\left(\Delta E^{\circ}>150 \mathrm{mV}\right)$ には分離した 2 つの波が観 測される.これは近似的に 2 種等濃度混合系の CV と して考えることができる(つまり，2つの CV 波の和で

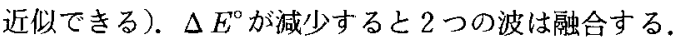
このような状況ではもはや $2 つ の C V$ 波に加成性は成 り立たない.たとえば, $\Delta E^{\mathrm{c}}=0$ の時, $\Delta E_{\mathrm{p}}$ は $42.2 \mathrm{mV}$ となり, 59/1 $\mathrm{mV}$ より小さくかつ 59/2 $\mathrm{mV}$ より大きい. 


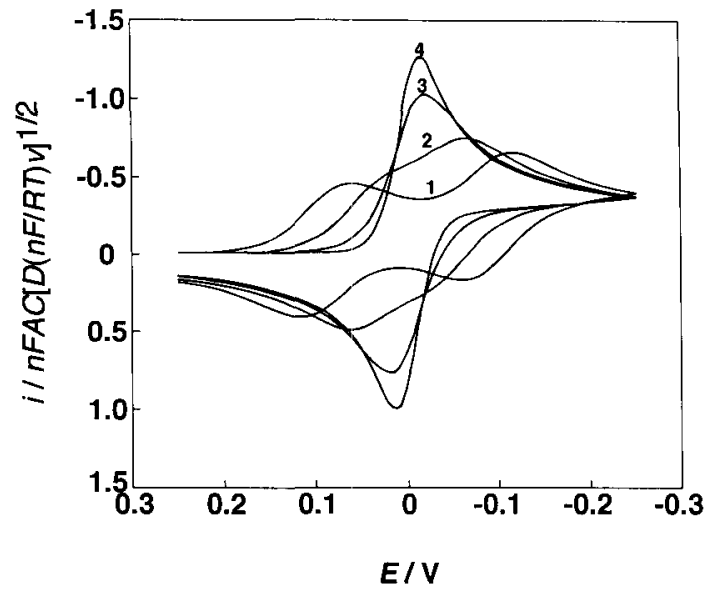

Fig. 1 Cyclic voltammograms for a reversible two-step one-electron system with $\left(E_{1}{ }^{\circ}+E_{2}{ }^{\circ}\right)=0$ $\mathrm{mV}$ and $\Delta E^{\circ}=(1): 180 \mathrm{mV}$, (2) $: 90 \mathrm{mV}$, (3) $: 0 \mathrm{mV}$, and (4) : $-180 \mathrm{mV}$.

更に $\Delta E^{\circ}$ が減少すると（つまり， $E_{1}{ }^{\circ}$ と $E_{2}{ }^{\circ}$ の逆転が大 きくなると）ピークは鋭くなり， $\Delta E^{\circ}<-180 \mathrm{mV}$ （現 実的には $100 \mathrm{mV}$ ) では 1 段階 2 電子反応系と全く同一 $\left(\Delta E_{\mathrm{p}}=59 / 2 \mathrm{mV}\right)$ になる.

こうした 2 段階 1 電子移動でその電位分離に興味がも たれるが，先に述べたような理由から単純には電位分離 できないのは, $-100 \mathrm{mV}<\Delta E^{\circ}<100 \mathrm{mV}$ の場合であ ろう。この場合，検量線を用いて $\Delta E_{\mathrm{p}}$ 等から $\Delta E^{\circ}$ を評 価する方法が提唱されている ${ }^{8}$ ので参照されたい，ただ し，これはあくまで線形拡散を仮定できる場合に限られ ることと可逆波について適用できることに注意して頂き たい，多次元拡散のある系や準可逆系では， $\Delta E_{\mathrm{p}}$ は大 きくなり， $\Delta E^{\circ}$ の過大評価となる。ピークの幅に関す る解析あるいはシミェレーションを用いるのが好ましい と思われる.

3 段階以上の電子移動では, 各段階の酸化還元電位差 が同一であるとは限らないので， 2 段階系のような $\Delta E_{\mathrm{p}}$ 々 $\Delta E^{\circ}$ の関係を示す検量線を作成するのは, 実際上不 可能となる.この場合の電位分離にはディジタルシミュ レーションを用いた解析が適切であろう。

\section{4 準可逆・非可逆系の CV}

可逆系であっても，v を増加すれば準可逆系になる。 近年の微小電極を用いた测定で， $v=100000 \mathrm{~V} / \mathrm{s}$ 程度 までの高速掃引が可能でおるから，現実的には，ほぼす ベての系を準可逆系として取り扱うことができる7゙. 準 可逆系 $\mathrm{CV} の \Delta E_{\mathrm{p}}$ は当然可逆系のそれより大き〈9), かつ， $i_{\mathrm{p}}$ は $v^{1 / 2}$ に比例しなくなる ${ }^{10)}$.この準可逆波の利 点は, 当然不均一電子移動速度に関する情報が得られる
ことである.この一般的解析法については既報2)を参照 されたい.またシミュレーションによる解析も汎用され ている、こうした準可逆波の波形は，可逆波のそれに似 ていることから，論文の著者によっては，準可逆的な性 質を持ち合わせているにあかかわらず，“可逆”という 表現を使用されている場合がある．以下では可逆・準可 逆系の総称として“可逆的”と表現させて頂く.

非可逆系は, 準可逆系の特殊な場合として取り扱うこ とができる，つまり，酸化還元の逆反応が現実的に進行 しないため，逆掃引においてピークは現れず，可逆的な 系の CV 波形とは異なり，一見して判別できる.しか しこの非可逆系を微視的に考えると, ほぼすべての場合 可逆電子移動 $\left(E_{\mathrm{r}}\right)$ に速い非可逆的化学反应 $\left(C_{\mathrm{i}}\right)$ か 後続し, その電位領域では酸化還元不活性なすのに变化 することによると言って過言ではない，つまり $E_{\mathrm{r}} C_{\mathrm{i}}$ 機 構である。この後続化学反応の寄与を軽减するには, 原 理上 $v$ を増加させれば良い，CV 波形を決定する要因は， 化学反応速度の絶対值ではなく，vに対する相対値であ るからである，通常の $v$ では非可逆な采でも，高速掃引 では可逆的な波として测定できる例が多くある7).ただ し $v$ との相対関係が重要であるという事情は, 不均一電 子移動速度についてもあてはまるので，化学反応速度の 方が電子移動速度より大きい場合には，高速掃引によっ ても，意味ある情報を得ることが困難であり，単純に “非可逆”という表現に留まらざるを得ない，残念なが ら,こうしたケースは少なくない。

\section{5 付随化学反応の影響}

電極反応に化学反伈が伴う系には良く遭遇し，この系 の解析から溶液反応に関する興味深い知見が得られる場 合が多い.ただしその反応機構は多種多様であるため, それらすべてについてここで述べることは困難である。 以下典型的な系を取り上げ，その CV 波の挙動につい て述べたい.

\section{1 可逆化学反応を伴う可逆電子移動}

この系の典型的な例は水溶液中でのキノン類の酸化還 元反応である : $\mathrm{Q}+2 \mathrm{e}^{-} \rightleftarrows \mathrm{Q}^{2-} \rightleftarrows \mathrm{QH}^{-} \rightleftarrows \mathrm{QH}_{2}$. 還元体で あるハイドロキノンは，酸塩基平衡伴っている．この 化学反応速度は早く可逆なため, CV は全体として可逆 である.今の場合, pHが減少するにつれ還元体の酸解 離平衡は左へ移るので，キノンはより還元され易くなる (系全体の酸化還元電位は正側へシフトする). 従ってこ の酸化還元電位のシフトを常法に従ってネルンスト解析 すれば，電子移動に伴うプロトン数や $\mathrm{p} K_{\mathrm{a}}$ を容易に求 めることが出来る.こうした例は酸解離平衡に限らず, 金属錯体形成平衡についても同様の取扱いができる.

ところが，このような単純なネルンスト解析が可能に なるのは，プロトンあるいは配位子の濃度勾配ができな 
いと仮定できる場合に限られる。配位子等の濃度が酸化 還元種濃度と同程度あるいはそれより少ない場合には, その化学反応の進行に伴い, 電極近傍で配位子濃度の減 少（あるいは増加）が起こる.こういう場合の理論的解 析は,ディジタシミュレーションに頼らざるを得ない. さらに可逆な構造変化を伴う場合も同様に可逆波が得ら れる.この場合, 高速掃引により構造変化の反忘速度を 相対的に減少させれば, 電子移動の素過程を分離して测 定出来る場合がある。

\subsection{ECE 機構}

これは例えば

$\mathrm{O}_{1}+\mathrm{e}^{-} \rightleftarrows \mathrm{R}_{1}$ (酸化還元電位 $: E_{1}{ }^{\circ}$ )

$\mathrm{R}_{1} \rightarrow \mathrm{O}_{2}$ (化学反応速度 : $k$ )

$\mathrm{O}_{2}+\mathrm{e}^{-\longrightarrow} \mathrm{R}_{2}$ (酸化還元電位 : $E_{2}{ }^{\circ}$ )

で表される反応である. $E_{2}{ }^{\circ}$ が $E_{1}{ }^{\circ}$ に比べて十分に負で あり，kがvに比べて十分大きければ，2つの分離した 波が観測され，第 1 波は非可逆，第 2 波は可逆（的）に なる. $k / v$ 比の减少と共に，第 1 波の可逆性が増し，第 2 波は小さくなる，状況はかなり単純である.

これに対して, $E_{2}{ }^{\circ}$ が $E_{1}{ }^{\circ}$ より正側に位置するときは 複雑になる．還元波はひとつしか現れず，その波は $k / v$ 比の上昇と共に $n=1$ の性格から $n=2$ の性格に移行す る. またその逆掃引の際のピークの現れ方も複雑である. この状況についてはシミュレーションで得られた CV 波の変化の様子が報告されている(1)ので参考にされた い.ただしこうした ECE 反応の場合, $\mathrm{R}_{1}+\mathrm{O}_{2} \rightleftarrows \mathrm{O}_{1}+$ $\mathrm{R}_{2}$ という溶液内電子交換反灾が起こり得ることを指摘 したい.この平衡定数は $K=(R T / F)\left(E_{2}{ }^{\circ}-E_{1}{ }^{\circ}\right)$ で あるから， $E_{2}{ }^{\circ}>E_{1}{ }^{\circ}$ の場合，この電子交換が起これば， $\mathrm{CV}$ 波は $\left(E_{1}{ }^{\circ}+E_{2}{ }^{\circ}\right) / 2$ の酸化還元電位を有する波に類 似したものになる，つまり，上記反応系で電子交換があ れば, $v$ の減少と共に(つまり $n=1$ の特性から $n=2$ の 特性に移行するに従い), 顕著に正電位側へシフトする ことになる ${ }^{12)}$. 先の参考文献 ${ }^{11)}$ も含め, これまでこう した溶液内電子交換反応を考慮していない例が多いので, $\mathrm{CV}$ 波に限らず ECE 系の電気化学測定の理論解析を行 う場合の重要な注意事項として頂きたい.

\section{3 触媒反応}

近年，バイオセンサーの開発，あるいは新規電極触媒 反忘の研究が活発に行われており，そうした過程でよく 遭遇するのが触媒反応を伴う電極反応の CVである。 その典型例を Fig. 2 に示す。この反応系は単純には R$\mathrm{e}^{-\rightleftarrows \mathrm{O}} ; \mathrm{O}+\mathrm{Z} \rightarrow \mathrm{R}+\mathrm{Y}$ (速度定数 : $k$ ) と表せる $(\mathrm{O} / \mathrm{R}$ : フェロセン誘導体で，Z：グルコース，そして化学反応 を触媒するのがグルコースオキシダーゼである).こう した触媒反応を伴う場合には，通常ピークは観測されず, シグモイド状の定常電流が得られる．触媒反応によって 定常的に R が電極近傍で再生され，枯渴が起こらない
からである，通常こうした定常電流 $\left(i_{\mathrm{s}}\right)$ は

$$
i_{\mathrm{s}}=n F A C(D k[\mathrm{Z}])^{1 / 2}
$$

で表され， $i_{\mathrm{s}}$ は $v$ に依存しなくなる，従って， $i_{\mathrm{s}}$ から容 易に $k$ を求めることができる.Fig. 2 のような酵素反 応を介する場合で $[Z]$ がミカエリス定数 $\left(K_{\mathrm{m}}\right)$ より 十分大きければ，反応層近似で $k[\mathrm{Z}]$ は $k^{\prime}[\mathrm{E}]$ ([E]: 酵素濃度）と置き換えられる，従って $k^{\prime}[\mathrm{E}]$ が十分大 きければメディエーター (O/R) の増幅検出が可能に なり，また， $k$ が大きけれ酵素の高感度分析に応用 できる。

(1)式のような単純な取り扱いができるのは，[Z]が Cに比べ十分に大きい場合（つまり電極近傍でのZ の 濃度分極が起こらないと仮定した場合）であることに注 意されたい，既報の中にはこの点に十分注意を払われて ないものも見受けられる。この仮定が成立しない場合は 数式は非常に複雑になり、ディジタルシミュレーション 解析を行うのが最も直接的であろう.

一方，触媒反応が電極表面で進行する場合， $i_{\mathrm{s}}$ は $[\mathrm{Z}]$ と比例関係にある.これが表面触媒を用いたセンサーの 基礎概念となる，ただし，酵素固定化した場合には， [Z]は $K_{\mathrm{m}}$ より十分小さい場合のみ， $i_{\mathrm{s}}$ が [Z] に比例 する。

$\mathrm{O} / \mathrm{R}$ の可逆酸化還元波の本来の大きさは先に述べた ように $v$ に依存するので, 結果として, 触媒反応の CV 波形に及ぼす影響は，vに対する相対的な値として現れ る. $v$ が小さければ，相対的に $i_{\mathrm{s}}$ が増加し，Fig. 2 のよ うな典型的な定常電流が観測されるのに対し， $v$ の増加

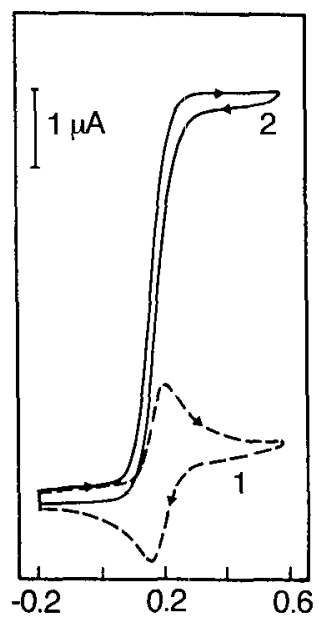

EIV vs. SCE

Fig. 2 Cyclic voltammograms of (1) $0.1 \mathrm{mM}$ of ferrocenemethanol and (2) its mediated and glucose oxidase $(2.7 \mu \mathrm{M})$-catalyzed oxidation of glucose at $v=80 \mathrm{mV} / \mathrm{s}$ and at $\mathrm{pH} 6.5$. 
と共に相対的に $i_{\mathrm{s}}$ の寄与が小さくなり，単純な可逆 (的) 波形に近づく.こうした特性を用いて，この反応機 構を見分けることができる. その他の化学反応関与の電 極反応の CV 波については，成書 ${ }^{11}$ 参考にされたい。

\section{6 吸 着 波}

CV 法による研究対象として，これまで述べてきた㹡 散種の酸化還元の他に，吸着種あるいは表面種の酸化還 元反応が挙げられる。これについても，本誌既報 ${ }^{3)}$ で詳 細に述べられているので，ここでは簡単に触れることに する.

可逆系に限って話を進めるならば，吸着種の CV 波 の特徴は，その $i_{\mathrm{p}}$ が $v$ に比例すること，そしてカソー ド波とアノ一ド波が電位軸に対して対称であることが挙 げられる，その波形は，拡散種の微分パルスボルタモグ ラム（パルス幅が非常に小さい場合）とほぼ同一になる。

しかしこうした純粋な可逆系（理想系）が測定できる ことはまれである。その理由は，これまでにも述べてき た電子移動速度の寄与あるいは付随化学反応の奇与といっ た因子の他に，電極表面て酸化還元種が隣接するため分 子間相互作用によりその活量係数が 1 で近似できなくな るからである.この取り报いに対しても多くの考え方が 報告されているが，比較的単純なものとして Frumkin 型相互作用を考虑したものが挙げられる ${ }^{3)}$. 一方，多電 子移動系を取り扱う場合は，前節で述べたような多段階 電子移動による理想系からのずれが引き起こされる場合 がある ${ }^{13)}$. 特に有機化合物の吸着波を扱った論文の中に は、この点に考慮を払わず解析しているものが多く見受 けられるので注意されたい，また酸化還元部位が長鎖ア ルキル基等を介して電極に結合している場合，界面二重 層での電位降下 (二重層効果) が現れ得る。このタイプ の修飾電極は現在注目されているあののひとつであるこ とから，実際の $i-E$ 曲線の解釈においては，こうした 界面での電位分布にも注意を払う必要があろう。最後に， このような吸着波には搪散の寄与がないので, 複雑な化 学反応系を伴ってもその電流電圧曲線を解析するのは比 較的容易である場合が多い㿣ことを付記しておく。

\section{7 ティジタルシミュレーション}

これまで，随所でシミュレーションによる解析につい て触れてきた. シミュレーションを用いる利点は, 数学 的には解きにくい反応系の $i-E$ 曲線を視覚的に表現で きることにある。その計算方法も多種にわたるが Feldberg らによるものが最も容易で広く受け入れられ ているように思われる ${ }^{11)}$. さらに, シミュレーションと 非線形最小自乗法を結び付け，実测 CV 波をフィッティ ングすることにより，それを特徴づける各種パラメーター を評価することができる ${ }^{14)}$. 最近ではシミュレーション
プログラムが市販され始めたが，それらは代表的な反応 系にしか適用できない欠点がある、研究者が遭遇する特 殊なケースについては，自らプログラムを作成せざるを 得ないのが現状である。1例として，可逆 4 電子酸化還 元反応系の CV 波のシミュレーション結果を Fig. 3 に 示した.この結果より，見かけ上 1 段階の反応が， 2 段 階 2 電子（あるいは逆転した酸化還元電位を有する 4 段 階 1 電子移動)であることが理解できる.

「シミュレーションによる解析と一言で片づけられて も，実際にどのように計算したのか，あるいはその計算 に信頼度はあるのか明確ではない.」と批判されること もないわけではないが，複雑な反纫系の解析には有力な 手段である，吸収スペクトルからその電子状態が考察で きるのは周知の通りである。しかしスペクトルそのあの を計算では再現できない。これに対して CV 波は基本 的には計算で再現し得るものであり，それによって，よ り多くの情報が得られることを御理解頂きたい.

\section{8 むすひ}

以上，CV 波の解积を中心にその注意点を含めて概説 させて頂いた，既報との重複を避け，また数式をできる だけ用いず表現したつもりであるが，良く知られている ことの繰り返し，あるいは筆者の興味に片寄った記述と

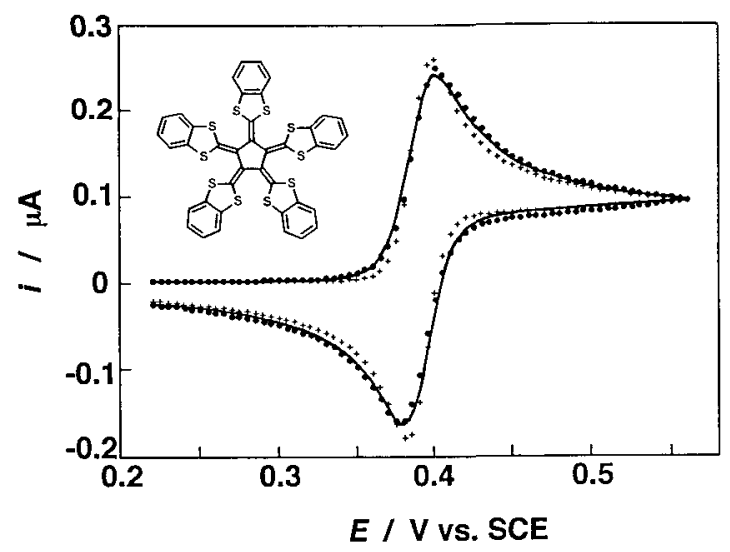

Fig. 3 Cyclic voltammograms of pentakis (1,3benzodithiol-2-ylidene) cyclopentane in benzonitrile at $v=5 \mathrm{mV} / \mathrm{s}(\mathbf{O})$. Solid line represents the regression curve simulated on the basis of a reversible two-step two-electron system $\left(E_{1}{ }^{\circ}=\right.$ $0.394 \mathrm{~V}, E_{2}^{\circ}=0.386 \mathrm{~V}$ ). An identical line is obtained based on a reversible four-step oneelectron system $\left(E_{1}{ }^{\circ}=0.434 \mathrm{~V}, E_{2}{ }^{\circ}=0.353 \mathrm{~V}, E_{3}{ }^{\circ}=\right.$ $\left.0.453 \mathrm{~V}, E_{4}{ }^{\circ}=0.317 \mathrm{~V}\right)$. Symbol $(+)$ represents the simulated curve calculated for a one-step fourelectron transfer system $\left(E^{\circ}=0.390 \mathrm{~V}\right)$. 
なった部分も多いことをお許し頂きたい，CV 法だけで 電極反応パラメーターを決定するのは，必ずしも好まし

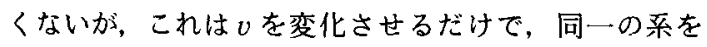
ms 加ら $\min に$ 加ての幅広い時間域で“見る”こと のできる测定法である．こうした意味から，CV 法を初 期崄断としてだけでなく，より高度な情報源として活用 されることを望む。

\section{文献}

1) 電気一重層容量に関係する電流 (nonfaradaic current) 季観測されるがこれについては本稿では触れないことに する.

2) 高村 勉, 電気化学, 39, 445 (1971).

3) 高村 勉, 佐藤祐一, 電気化学, 40, 265 (1972); 40, 324 (1972); 48, 221 (1980); 49, 474 (1981).

4) 大坂武男, 電気化学, 54, 110 (1986).

5）酸化之還元の速度差が電流之なって観測される。従って, 速度定数加十分に大きいときには，その速度定数の比， つまり Nernst 式で界面㳻度比が規定される。

6）青木幸一, 電気化学, 56, 608 (1988).

7) 咸崎 敏, 田中和子; 電気化学, 60, 771 (1992).

8) D.F. Richardson and H. 'Taube, Inorg. Chem., 20, 1278 (1981).
9）本来可逆系であるにすかかららず， $\Delta E_{\mathrm{p}}$ が理論値より大 きくなる要因として，先に述べた多次元拡散と多段階電 子移動によるものの他に, 未㭪償 IR 損失 (参照電極々 作用電極間の溶液抵抗に起因方る電厈降下）によるもの がある. CVの解析にあたっては、この点に常に留意す る必要がある。 未補偩 IR 損失を㧕えるためには，参照 電橔を作用電極に近づけるか, 微小電極を用いて電流を 小さくするか，あるいは正帰還回路をポテンショスタッ 卜に組み込むことが考えられる。

10）比較的㹟い範国でのvの変化に対しては，実際上 $i_{\mathrm{p}}$ と $v^{1 / 2}$ は直線関係を示す，従って， $i_{\mathrm{p}}$ 之 $v^{1 / 2}$ の直線関係だけ 加ら可逆・準可逆を決定するのは位険である。線形搪散 の場合, 可逆波の $\Delta E_{\mathrm{p}}$ はしに依存しないのに対して, 準 可逆波は，vの增加と共に $\Delta E_{\mathrm{p}}$ 增加する，さらに，後 者の現象は未補偵 IR 損失によっても引き起こされる。 このように可逆・準可逆の区別に関しては，細心の注意 を要する。

11) A.J. Bard and L.R. Faulkner, "Electrochemical Methods", Wiley, New York (1980)

12）電子交換反沁加起こらない場合でも，いわゆる $\mathrm{EC}$ 機構 で観測されるようなvの減少に伴う正電位シフトが観測

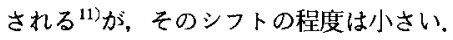

13) K. Kano and B. Uno, Anal. Chem., 65, 1088 (1993).

14）加納健司，後藤正志，ぶんせき，1991，981. 